\title{
Evaluation of the action of precipitating agents to obtain allergenic proteins from crude mite extracts
}

\author{
Avaliação da ação de agentes precipitantes na obtenção de \\ proteínas alergênicas presentes em extratos brutos de ácaros
}

\author{
Francisca das Chagas Sobral Silva ${ }^{1,2}$, Daniel Vasconcelos Silva², Anderson Bruno Matos ${ }^{2}$, \\ Andrea Medeiros Salgado', Maria Queiroz da Cruz ${ }^{2}$
}

\section{ABSTRACT}

Introduction: Allergen proteins found in dust mite extracts, such as Dermatophagoides farinae (DF), Dermatophagoides pteronyssinus (DP) and Tyrophagus putrescentiae (TP), are relevant for scientific studies in the allergy and immunotherapy fields. The precipitation/concentration of protein extracts may favor the aggregation of the allergens in homogenates. Objective and method: This paper investigates the precipitation process by submitting crude mite extracts to compounds such as ammonium sulfate $\left(\mathrm{NH}_{4}\right)_{2} \mathrm{SO}_{4}$, trichloroacetic acid (TCA) and acetone. Results: The best results were obtained by fractionation with $\left(\mathrm{NH}_{4}\right)_{2} \mathrm{SO}_{4}$ at $80 \%(\mathrm{w} / \mathrm{v})$ saturation $\left(\sim 0^{\circ} \mathrm{C}\right)$, observing the protein markings on the electrophoresis gel. Major allergens were identified by immunoblot at $25 \mathrm{kDa}$ (cysteine protease) for Der $\mathrm{f}$ and Der p; and $25 \mathrm{kDa}, 30 \mathrm{kDa}$ (tropomyosin) and Try p 3, near 26 $\mathrm{kDa}$. For this percentage the total protein contents were $12.83 \mathrm{mg}$ $\mathrm{mL}^{-1}$ for Der f, $24.78 \mathrm{mg} \mathrm{mL}^{-1}$ for Der $\mathrm{p}$ and $27.35 \mathrm{mg} \mathrm{mL}^{-1}$ for Try. Conclusion: An advantage of precipitation with $\left(\mathrm{NH}_{4}\right)_{2} \mathrm{SO}_{4}$ over precipitation with acetone was the possibility of gradually obtaining protein fractions, which does not happen when using the latter. The addition of $80 \%(\mathrm{v} / \mathrm{v})$ acetone to the mite extracts favored total protein precipitation in the concentrations $16.42 \mathrm{mg} \mathrm{mL}^{-1}, 28.47$ $\mathrm{mg} \mathrm{mL}^{-1}$ and $13.41 \mathrm{mg} \mathrm{mL}^{-1}$. The use of TCA in concentrations above $20 \%(\mathrm{w} / \mathrm{v})$ forms peptides that are not retained in the gel under the established experimental conditions, and dilute solutions of this acid are more efficient.

Keywords: Mites, proteins, allergens, types of precipitation.

\section{RESUMO}

Introdução: As proteínas alergênicas presentes nos extratos dos ácaros de poeira, tais como Dermatofagoides farinae (DF), Dermatofagoides pteronyssinus (DP) e Tyrophagus putrescentiae (TP) são relevantes para estudos científicos na área de alergias e aplicação em imunoterapias. A precipitação/concentração desses extratos proteicos pode favorecer a agregação de alérgenos nos homogenatos. Objetivo e método: $O$ trabalho investiga o processo de precipitação, submetendo os extratos brutos de ácaros de poeira a compostos como sulfato de amônio $\left(\mathrm{NH}_{4}\right)_{2} \mathrm{SO}_{4}$, ácido tricloroacético (ATC) e acetona. Resultados: Os melhores resultados foram obtidos por fracionamento com $\left(\mathrm{NH}_{4}\right)_{2} \mathrm{SO}_{4} \mathrm{em} 80 \%$ $(\mathrm{m} / \mathrm{v})$ de saturação $\left(\sim 0^{\circ} \mathrm{C}\right)$, observando as marcações proteicas no gel de eletroforese. Os alérgenos principais foram identificados por immunoblot em $25 \mathrm{kDa}$ (cisteína protease) para Der $\mathrm{f} 1$ e Der p 1; e 25 kDa, 33 kDa (tropomyosin), 11 kDa para Tyr. Para esse percentual, os teores de proteína total foram de $12.83 \mathrm{mg}$ $\mathrm{mL}^{-1}$ para DF; $24,78 \mathrm{mg} \mathrm{mL}^{-1}$ para DP; e $27,35 \mathrm{mg} \mathrm{mL}^{-1}$ para TP. Conclusão: $A$ vantagem da precipitação com $\left(\mathrm{NH}_{4}\right)_{2} \mathrm{SO}_{4}$ frente à precipitação com acetona foi a possibilidade de gradativamente se obter frações proteicas, o que não acontece quando utilizado esse solvente. A adição de $80 \%$ (v/v) de acetona aos extratos de ácaros favoreceu a precipitação total de proteína nas concentrações $16,42 \mathrm{mg} \mathrm{mL}^{-1} ; 28,47 \mathrm{mg} \mathrm{mL}^{-1}$; e $13,41 \mathrm{mg} \mathrm{mL}^{-1}$. O uso de ATC em concentrações acima de $20 \%(\mathrm{~m} / \mathrm{v})$ forma peptídeos que não são retidos no gel nas condições experimentais estabelecidas, sendo eficiente soluções mais diluídas desse ácido.

Descritores: Ácaros, proteínas, alérgenos, tipos de precipitação.

1. Federal University of Rio de Janeiro, Chemical Engineering Department - Rio de Janeiro, RJ, Brazil.

2. Allergenic Extracts Laboratory, Research and Development - Rio de Janeiro, RJ, Brazil.

Funding source: Laboratory of Allergen Extracts LTDA, Brazil.

Submitted: 1/14/2020, accepted: 2/20/2020.

Arq Asma Alerg Imunol. 2020;4(1):121-8.

http://dx.doi.org/10.5935/2526-5393.20200011 


\section{Introduction}

The allergens found in dust mites are of great relevance for the pharmaceutical industry and are employed in many research fields in healthcare. These allergens are specific proteins that are able to cause severe mucosal inflammation, leading to rhinitis and bronchitis. ${ }^{1,2}$ The most common house dust mites for immunotherapy with mite extracts are Dermatophagoides farinae, Dermatophagoides pteronyssinus, Blomia tropicalis and Tyrophagus putrescentiae,,$^{3-5}$ and therefore, these mites have greater sensibilization indexes in groups of individuals diagnosed with allergies. ${ }^{6,7}$ The main allergens found in mite extracts are from group 1, as follows: for Der f 1: $25 \mathrm{kDa}$ (cystein protease), Der f 3: $29 \mathrm{kDa}$ (trypsin), Der f 10: $37 \mathrm{kDa}$ (tropomyosin) and Der f 2: $15 \mathrm{kDa}$ (NPC2 family); for Der p 1:24 kDa (cysteine protease), Der $\mathrm{p}$ 2: $15 \mathrm{kDa}$ (NPC2 family) and Der p 3: $31 \mathrm{kDa}$ (trypsin), among others, according to the allergen.org platform. For the Tyrophagus putrescentiae mite, the main allergens are Tyr $\mathrm{p} 2$ : 16 kDa (NPC2 family), Tyr p 3: 26 kDa (trypsin), Tyr p 10: $33 \mathrm{KDa}$ (tropomyosin), Tyr p 13: $15 \mathrm{kDa}$ (fatty-acid binding protein), Tyr $\mathrm{p} 28: 76 \mathrm{kDa}$ (heat shock protein), Tyr p 34: $18 \mathrm{KDa}$ (troponin C), Tyr p 35: $52 \mathrm{kDa}$ and Tyr p 36; $14 \mathrm{kDa}$ (profilin). ${ }^{8}$

A strategy for obtaining allergenic proteins is to expose the raw extract obtained from the mites to chemical substances capable of favoring protein isolation, pre-purification or concentration of these antigens. An interesting method that can be successfully used for protein fractionation purposes is the application of ammonium sulfate, $\left(\mathrm{NH}_{4}\right)_{2} \mathrm{SO}_{4}$, as a precipitating agent. ${ }^{9}$ In this procedure there is interaction of water with salt ions in the medium, leading to a reduction in protein solvation by water molecules due to a change in the ionic strength of the medium. Depending on the characteristics of the protein, such as size, charge and isoelectric point (pl), the saturation of the medium may be adjusted at a given temperature to allow selective precipitation to occur. Also, some water-soluble solvents and organic acids may be used for precipitation. ${ }^{10,11}$

Acetone and ethanol are some of the most used solvents, allowing the solvation effect with lowering of the dielectric constant to occur and favoring protein precipitation. It is necessary, however, to conduct the procedure at low temperatures to avoid solvent denaturation. The trichloroacetic acid (TCA) forces the protein to precipitate by isolating the water around it and has the advantage of total or partial removal of high molecular weight proteins and peptides, and the precipitation rate depends on the type of protein and precipitate, as well as their respective concentrations. ${ }^{12,13}$ Due to a high demand in areas such as vaccine research, immunotherapy and diagnostic procedures, there is a great need for the isolation and concentration of allergens found in mites from crude extracts. Thus, the present paper aimed to investigate and evaluate pre-purification and concentration methods that allow obtaining allergenic proteins from the removal of impurities present in the crude extracts of house dust mites, in order to employ these allergens in different immunochemical procedures.

\section{Experimental section}

\section{Extract preparation}

Mite cultivation and crude extract preparation were conducted as described by Mihos. ${ }^{14}$ Dust samples were collected at households in the city of Rio de Janeiro, Brazil. Mites were isolated from 80 samples of mesh aspirated powder and identified by taxonomic reference catalogues and identification keys. ${ }^{15,8}$ The preparation of the extracts were conducted following the procedure described by Mihos. ${ }^{14}$

\section{Application of D. farinae, D. pteronyssinus and T. putrescentiae pre-purification methods}

\section{$\left(\mathrm{NH}_{4}\right)_{2} \mathrm{SO}_{4}$ fractioning}

The crude mite extracts were sequentially fractionated with $\left(\mathrm{NH}_{4}\right)_{2} \mathrm{SO}_{4}$, as described by Scopes. ${ }^{16}$ Fractioning was done in the ranges of $0-20 \%$ (2.82 g), 20-40\% (3.02 g), 40-60\% (3.25 g), 60-80\% $(3.50 \mathrm{~g})$ and $80-100 \%(3.80 \mathrm{~g})(\mathrm{w} / \mathrm{v})$ of saturation. The percentages of added salt were determined in relation to the volume of the extract, considering a $50.0 \mathrm{~mL}$ sample, Scopes (1994). During precipitation, the sample remained in an ice bath at a temperature of approximately $0{ }^{\circ} \mathrm{C}$ for a period of $60-90$ minutes. After this time the extract was centrifuged at $5724 \mathrm{xg}$ under refrigeration at $4{ }^{\circ} \mathrm{C}$ for 20 minutes. This process was repeated for all saturation intervals. The pellets from each interval were resuspended in $5.0 \mathrm{~mL}$ of ultrapure water. The pre-purified extracts were stored at $-20^{\circ} \mathrm{C}$ for subsequent determination of protein content.

\section{Acetone precipitation}

A $50.0 \mathrm{~mL}$ sample of the crude extract of the study mites was added separately in ice-wrapped containers. For each extract volume were added $20 \%$ 
$(\mathrm{v} / \mathrm{v}), 40 \%(\mathrm{v} / \mathrm{v}), 60 \%(\mathrm{v} / \mathrm{v}), 80 \%(\mathrm{v} / \mathrm{v})$ and $100 \%(\mathrm{v} / \mathrm{v})$, respectively. Acetone was previously cooled to $-20^{\circ} \mathrm{C}$. The pellet formed was centrifuged at $5724 \mathrm{xg}$ at $4{ }^{\circ} \mathrm{C}$ for 30 minutes and then resuspended in $5.0 \mathrm{~mL}$ of ultrapure water.

\section{TCA precipitation}

The percentages of $20 \%(\mathrm{w} / \mathrm{v}), 40 \%(\mathrm{w} / \mathrm{v}), 60 \%$ $(\mathrm{w} / \mathrm{v}), 80 \%(\mathrm{w} / \mathrm{v})$ and $100 \%(\mathrm{w} / \mathrm{v})$ of TCA were individually added to $50.0 \mathrm{~mL}$ of crude mite extract. After 30 minutes of gentle shaking the pellet formed was centrifuged at $5724 \mathrm{xg}$ at $4{ }^{\circ} \mathrm{C}$ for 30 minutes and then resuspended in $5.0 \mathrm{~mL}$ of ultrapure water. The precipitates formed and the supernatant were stored at $-20^{\circ} \mathrm{C}$ for further analysis.

\section{Precipitate characterization}

\section{Total protein content determination}

The protein content of precipitates and supernatants for each pre-purification sample were determined by the Lowry method according to the literature. ${ }^{17} \mathrm{An}$ analytical curve was built from the standard bovine serum albumin protein (BSA, Sigma-Aldrich) in the range of $5.0 \mu \mathrm{g} \mathrm{mL}^{-1}$ to $100.0 \mathrm{\mu g} \mathrm{mL}^{-1}$. In a test tube $1.0 \mathrm{~mL}$ of the BSA standard solution was added; $1.0 \mathrm{~mL}$ of alkaline copper reagent in 1:2:1 ratio of $0.1 \%(\mathrm{w} / \mathrm{v})$ copper sulfate, sodium dodecyl sulfate (SDS), 3.2\% (w/v) sodium hydroxide, respectively. After homogenization, the tubes were left to stand and $500 \mu \mathrm{L}$ of diluted Folin-Ciocalteu reagent was added in a proportion of 1:5. The tubes were kept in the dark for $30 \mathrm{~min}$. Absorbance readings were taken at $750 \mathrm{~nm}$ using ultraviolet-visible spectrophotometer (Spectrophotometer SP 1102, Bel photonics, Brazil).

\section{Protein characterization by SDS-PAGE}

The profile of the protein found in the precipitates and supernatants was determined by denaturing electrophoresis according to the method described by Laemmli. ${ }^{18}$ The gel was prepared by polymerization of $30 \%(29: 1)$ acrylamide/bis-acrylamide reagent (Bio-Rad). The resolving gel was prepared at $12 \%$ acrylamide/bis-acrylamide, and the stacking gel was prepared at $5.0 \%$ reagent concentration. The polymerization started after the addition of $1.0 \%(\mathrm{w} / \mathrm{v})$ ammonium persulfate. Samples applied to the gel were diluted $1: 1$ in mercaptoethanol and bromophenol blue sample buffer solution.

\section{Reactivity of allergenic extracts by immunoblotting}

In order to evaluate the reactivity and stability of the fractions obtained from the $\left(\mathrm{NH}_{4}\right)_{2} \mathrm{SO}_{4}$ precipitation process, some samples were taken for reactivity testing against the serum of individuals diagnosed with allergies to dust mites. The fractions were selected considering the highest protein concentration obtained by the precipitation method. After electrophoretic run of the samples, the proteins separated by molecular weight were transferred to the nitrocellulose membrane with $0.45 \mu \mathrm{m}$ pores (Bio-Rad) in a transfer module under conditions of $10 \mathrm{mV}, 1 \mathrm{~W}$ for $18 \mathrm{~h}$ at $8{ }^{\circ} \mathrm{C}$, using as saline buffer $\mathrm{pH}$ electrolytic solution with $\mathrm{pH}=7.2$, consisting of $25 \mathrm{mM}$ Tris-base, $192 \mathrm{mM}$ glycine and 20\% methanol. After the transfer, the membrane containing proteins was left in contact for 30 minutes with $5 \%(\mathrm{w} / \mathrm{v})$ BSA solution to block non-membrane bound sites. After washing with TBS-T (Tris-buffered saline with Tween), the membrane was incubated in a 1:200 diluted serum pool for 40 minutes. The washing process was repeated, and the membrane was incubated in 1:2000 diluted peroxidase-conjugated anti-IgE solution. The spots related to the antigen-antibody reactivity were identified using 4-Chloro-2-nitrophenol reagent in the presence of hydrogen peroxide.

\section{Results and Discussion}

The protein content quantification of $D$. farinae, $D$. pteronyssinus and $T$. putrescentiae for the different pre-purification/concentration methods was determined according to Lowry. ${ }^{17}$ The results are shown in Tables 1, 2 and 3.

\section{$\left(\mathrm{NH}_{4}\right)_{2} \mathrm{SO}_{4}$ precipitation}

As shown in Table 1, in the sequential fractionation precipitation method with $\left(\mathrm{NH}_{4}\right)_{2} \mathrm{SO}_{4}$, distinct molecular weight protein fractions were obtained at different times of the process. This can be observed from the protein content retained in the electrophoresis gel in the percentages of $20 \%$ in comparison with the other percentages, which was found in all fractions of mite extracts used in the study (Figure 1).

For the $D$. farinae mite extract, the salt saturation percentage at $20 \%(\mathrm{w} / \mathrm{v})$ favored the precipitation of proteins smaller than $15 \mathrm{kDa}$ that left the gel pores during the electrophoretic run. This finding was confirmed by the absence of proteins in the $12.5 \%$ 
Table 1

Protein content $\left(\mathrm{mg} \mathrm{mL}^{-1}\right)$ of dust mite extracts after $\left(\mathrm{NH}_{4}\right)_{2} \mathrm{SO}_{4}$ fractionation process, at $\sim{ }^{\circ} \mathrm{C}$.

\begin{tabular}{|c|c|c|c|c|c|c|c|}
\hline Mite & Crude extract & $\begin{array}{c}0-20 \% \\
(w / v)\end{array}$ & $\begin{array}{c}20-40 \% \\
\text { (w/v) }\end{array}$ & $\begin{array}{c}40-60 \% \\
(w / v)\end{array}$ & $\begin{array}{c}60-80 \% \\
(w / v)\end{array}$ & $\begin{array}{c}80-100 \% \\
(w / v)^{\star}\end{array}$ & $\mathrm{s}$ \\
\hline DF & $4.84( \pm 0.05)$ & $14.77( \pm 0.65)$ & $18.00( \pm 0.67)$ & $11.22( \pm 0.37)$ & $12.83( \pm 0.49)$ & $9.61( \pm 0.49)$ & ND \\
\hline DP & $4.45( \pm 0.05)$ & $15.42( \pm 1.16)$ & $21.87( \pm 0.67)$ & $19.29( \pm 0.85)$ & $24.78( \pm 0.19)$ & $17.67( \pm 1.45)$ & ND \\
\hline TP & $6.20( \pm 0.00)$ & $3.84( \pm 0.09)$ & $24.74( \pm 0.00)$ & $28.96( \pm 0.00)$ & $27.35( \pm 1.30)$ & $22.51( \pm 0.85)$ & ND \\
\hline
\end{tabular}

$\mathrm{DF}=$ Dermatophagoides farinae, $\mathrm{DP}=$ Dermatophagoides pteronyssinus, $\mathrm{TP}=$ Tyrophagus putrescentiae, $\mathrm{S}=$ supernatant, $\mathrm{ND}=$ not determined.

Table 2

Lowry protein content $\left(\mathrm{mg} \mathrm{mL}^{-1}\right)$ for dust mite extracts after precipitation process with TCA, \% in w/v

\begin{tabular}{lcccccc}
\hline Mite & Crude extract & $\begin{array}{c}20 \% \\
(w / v)\end{array}$ & $\begin{array}{c}40 \% \\
(w / v)\end{array}$ & $\begin{array}{c}60 \% \\
(w / v)\end{array}$ & $\begin{array}{c}80 \% \\
(w / v)\end{array}$ & $\begin{array}{c}100 \% \\
(w / v)\end{array}$ \\
\hline DF & $4.45( \pm 0.01)$ & $7.06( \pm 0.34)$ & $10.45( \pm 0.56)$ & $7.87( \pm 0.32)$ & $8.03( \pm 0.25)$ & $7.87( \pm 0.43)$ \\
S & - & $17.35( \pm 1.61)$ & $10.58( \pm 0.65)$ & $9.93( \pm 1.34)$ & $10.25( \pm 1.97)$ & $8.96( \pm 0.19)$ \\
DP & $4.84( \pm 0.01)$ & $8.32( \pm 0.32)$ & $6.71( \pm 0.99)$ & $6.38( \pm 0.32)$ & $5.09( \pm 0.37)$ & $3.80( \pm 0.56)$ \\
S & - & $\mathrm{ND}$ & $5.85( \pm 0.00)$ & $5.15( \pm 0.11)$ & $25.74( \pm 0.15)$ & $17.67( \pm 0.21)$ \\
TP & $6.20( \pm 0.01)$ & $18.00( \pm 0.97)$ & $12.84( \pm 1.16)$ & $4.77( \pm 0.65)$ & $4.13( \pm 0.65)$ & $4.45( \pm 0.32)$ \\
S & - & $17.35( \pm 0.34)$ & $10.58( \pm 0.32)$ & $9.93( \pm 0.81)$ & $10.25( \pm 0.16)$ & $8.96( \pm 0.09)$ \\
\end{tabular}

DF = Dermatophagoides farinae, DP = Dermatophagoides pteronyssinus, $\mathrm{TP}=$ Tyrophagus putrescentiae, $\mathrm{S}=$ supernatant.

Table 3

Protein content $\left(\mathrm{mg} \mathrm{mL}^{-1}\right)$ for dust mite extracts after acetone precipitation process, \% (w/v)

\begin{tabular}{lcccccc}
\hline Mite & Crude extract & $\begin{array}{c}20 \% \\
(w / v)\end{array}$ & $\begin{array}{c}40 \% \\
(w / v)\end{array}$ & $\begin{array}{c}60 \% \\
(w / v)\end{array}$ & $\begin{array}{c}80 \% \\
(w / v)\end{array}$ & $\begin{array}{c}100 \% \\
(w / v)\end{array}$ \\
\hline DF & $4.45( \pm 0.01)$ & $11.69( \pm 0.37)$ & $14.49( \pm 2.60)$ & $16.42( \pm 0.37)$ & $16.42( \pm 0.37)$ & $17.93( \pm 0.37)$ \\
DP & $4.84( \pm 0.01)$ & $13.63( \pm 0.37)$ & $22.02( \pm 0.37)$ & $26.75( \pm 0.37)$ & $28.47( \pm 0.37)$ & $25.46( \pm 0.99)$ \\
TP & $6.20( \pm 0.00)$ & $2.44( \pm 0.37)$ & $5.67( \pm 0.04)$ & $10.83( \pm 0.98)$ & $13.41( \pm 1.34)$ & $14.70( \pm 0.74)$ \\
\hline
\end{tabular}

$\mathrm{DF}=$ Dermatophagoides farinae, $\mathrm{DP}=$ Dermatophagoides pteronyssinus, $\mathrm{TP}=$ Tyrophagus putrescentiae, $\mathrm{S}=$ supernatant. 
acrylamide/bis-acrylamide gel (Figure 1A). However, although the highest protein content was identified at $40 \%(\mathrm{w} / \mathrm{v})$ saturation $\left(18.00 \mathrm{mg} \mathrm{mL}^{-1}\right)$ (Table 1$)$, it showed a low concentration of the allergenic protein of interest, cysteine protease, of $25 \mathrm{kDa}$ molecular weight, which was identified in higher concentration in the $60-80 \%$ saturation fraction.

Cysteine protease has relevance in the field of immunotherapy and is a major dust mite allergen, classified in allergen group $1 .{ }^{19}$ For the other mites the $80 \%(\mathrm{w} / \mathrm{v})$ saturation percentage also showed better separation with protein contents of $24.78 \mathrm{mg}$ $\mathrm{mL}^{-1}$ and $27.35 \mathrm{mg} \mathrm{mL}^{-1}$ for the $D$. pteronyssinus and T. putrescentiae mites, respectively (Table 1).

For the fractions obtained in the supernatants, after $100 \%(w / v)$ saturation, due to the low protein content, it was not possible to determine the protein levels within the detection limit proposed by the Lowry standard method. ${ }^{16}$ In view of the results obtained in the electrophoretic run (Figure 1) the fractionation separation process was maintained in the $80 \%(\mathrm{w} / \mathrm{v})$ $\left(\mathrm{NH}_{4}\right)_{2} \mathrm{SO}_{4}$ pre-purification fraction. This saturation percentage was used to evaluate the immunochemical reactivity between allergenic protein and serum IgE by western blot technique.

\section{TCA}

The fractions collected from the precipitate and supernatant by the 2,2,2-TCA precipitation method showed a similar protein content, which indicates an efficient decrease when compared to the salting-out method using $\left(\mathrm{NH}_{4}\right)_{2} \mathrm{SO}_{4}$ in the same percentages of interest (Table 2).

The poor $12.2 \%$ gel protein retention in percentages above $20 \%$ (w/v) (TCA) was observed by the electrophoresis test for the $D$. farinae mite extract (Figure 2). It can be inferred that, in percentages above $20 \%(\mathrm{w} / \mathrm{v})$, and therefore a more acidic solution, peptide hydrolysates are formed and are not retained in the gel, remaining only proteins greater than $20 \mathrm{kDa}$ in the polyacrylamide mesh. Also, the percentages of interest for the precipitation with TCA acid must be well below $20 \%(\mathrm{w} / \mathrm{v})$ to preserve the protein structure and to obtain a good separation profile, being the target of investigation. In another study, Rajalingam et al. ${ }^{10}$ evaluated protein precipitation (lysozyme, carbonic anhydrase and BSA) in a 0-90\% (w/v) saturation range with TCA and obtained higher protein precipitation in $45 \%(w / v)$ of the acid. However, the authors reported that depending on the protein structure, percentages below $5 \%(\mathrm{w} / \mathrm{v})$ are enough for the protein structure to
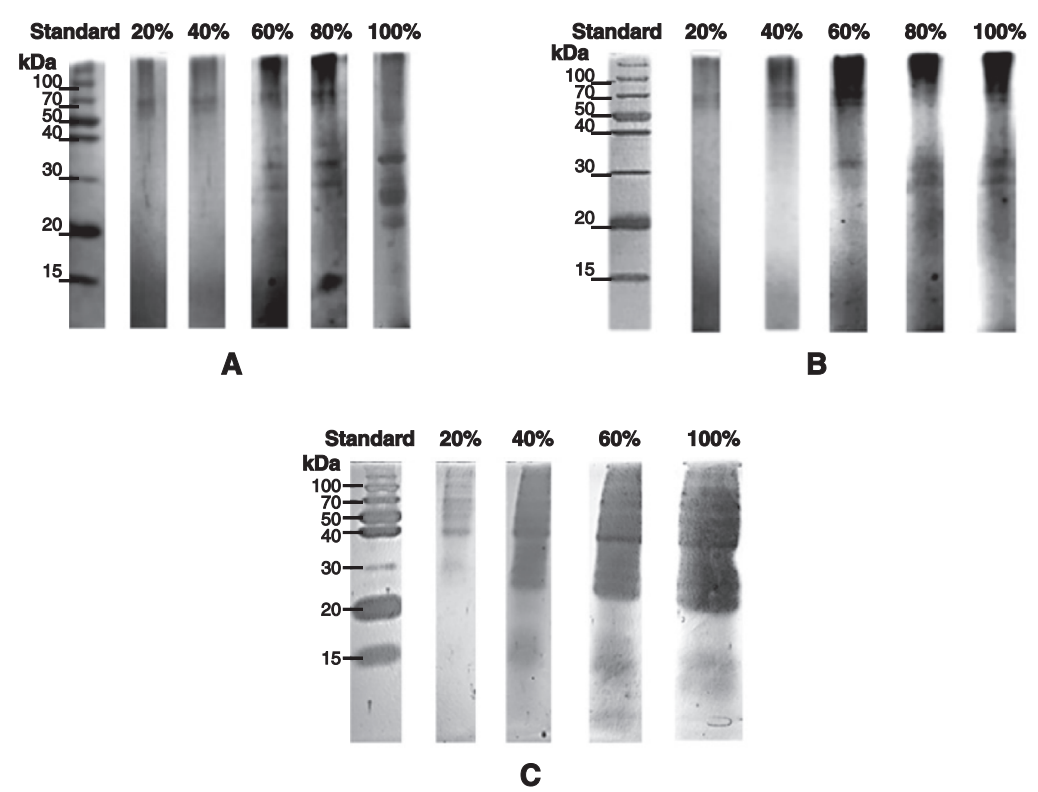

Figure 1

SDS-PAGE 12.5\% under denaturing conditions for (A) Dermatophagoides farinae, (B) Dermatophagoides pteronyssinus and (C) Tyrophagus putrescentiae 
unfold, exposing solvent-accessible non-polar surfaces and thus resulting in coalescence and precipitation. For the other acrylamide/bis-acrylamide gel mites they did not report electrophoretic gait.

Precipitation with acetone is a very useful method when the aim is to obtain a protein concentrate from an extract, either animal or vegetable. In order to evaluate the established working percentages of 20 to $100 \%$ of the precipitating agents in this study, the percentage concentration with solvent was evaluated using acetone for the allergenic extracts of the $D$. farinae, D. pteronyssinus and T. putrescentiae mites, as shown in Table 3.

According to the protein contents obtained (Table $3)$, there is an increasing trend in precipitation with the addition of acetone. The electrophoresis gel indicates that there is no selection of protein fractions, but actually full protein loading under the established conditions. These results show that the solvent method is more efficient for concentration purposes, and one strategy for isolation of these is the application of exclusion chromatography, for example.

Precipitation trends and efficiency of the methods applied for pre-purification and allergen concentrations can be better seen in the curves obtained for the mite extracts, as shown in Figure 4A, 4B and 4C.

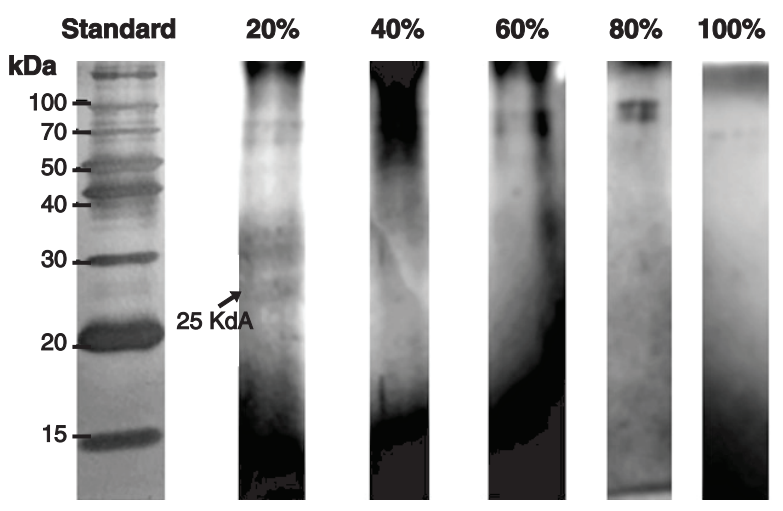

Figure 2

SDS-PAGE $12.5 \%$ under denaturing conditions for precipitation of allergic extracts for Dermatophagoides farinae with trichloroacetic acid (TCA)

\section{Allergenic protein reactivity}

The confirmation of allergen reactivity for protein fractions obtained in the fractionation process with $80 \%(\mathrm{w} / \mathrm{v})$ of $\left(\mathrm{NH}_{4}\right)_{2} \mathrm{SO}_{4}$ salt is shown in Figure 5.

Antigen-antibody reactivity was confirmed when added in contact with serum pool of individuals diagnosed with allergy to the mites under study, containing specific IgE, which were identified at 25 $\mathrm{kDa}$, for Der $\mathrm{f} 1$ and Der $\mathrm{p} 1$ indicating the presence

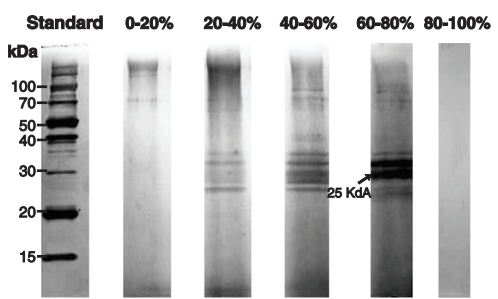

A

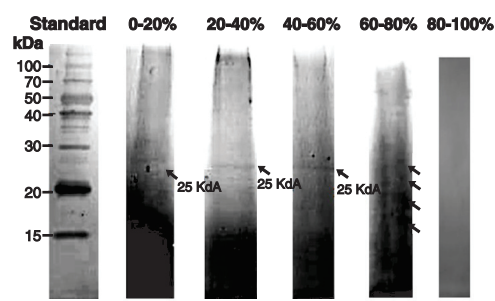

B

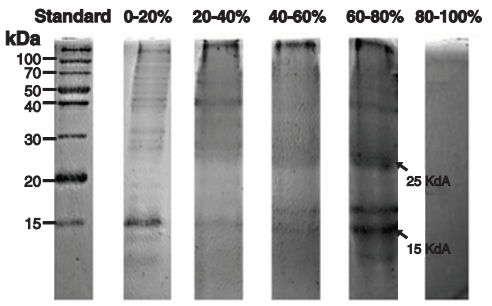

C

Figure 3

SDS-PAGE (12\% acrylamide/bis-acrylamide) under denaturing conditions for (A) Dermatophagoides farinae, (B) Dermatophagoides pteronyssinus and (C) Tyrophagus putrescentiae 
of the allergen group 1, cysteine protease. For $T$. putrescentiae mite, reactivity in the blot characterizes the allergens Try p 3, close to $26 \mathrm{kDa}$, for trypsin, and Try $\mathrm{p} 10$, close to $30 \mathrm{kDa}$, for tropomyosin. Especially for T. putrescentiae mite, reactivity occurred for protein fractions close to $10 \mathrm{kDa}$, and this fraction was also visible in the SDS-PAGE gel (Figure 1C), below 15 $\mathrm{kDa}$. For this allergen, a characterization study with proteomic analysis is necessary.

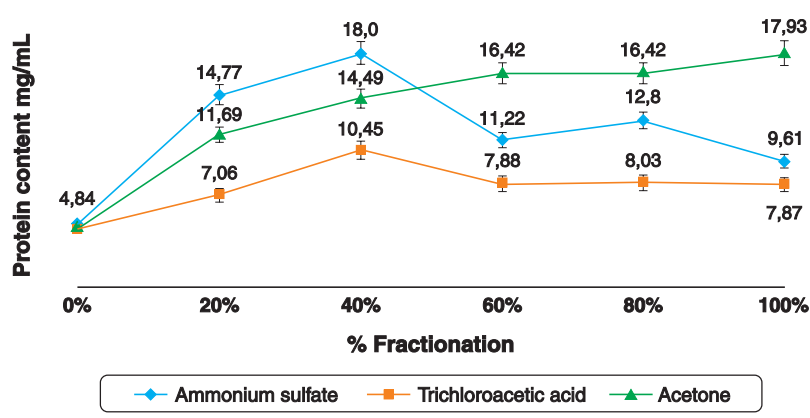

(A) Dermatophagoides farinae

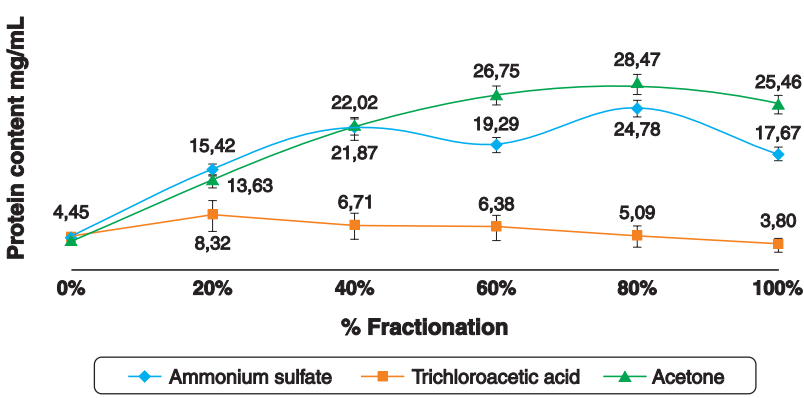

(B) Dermatophagoides pteronyssinus

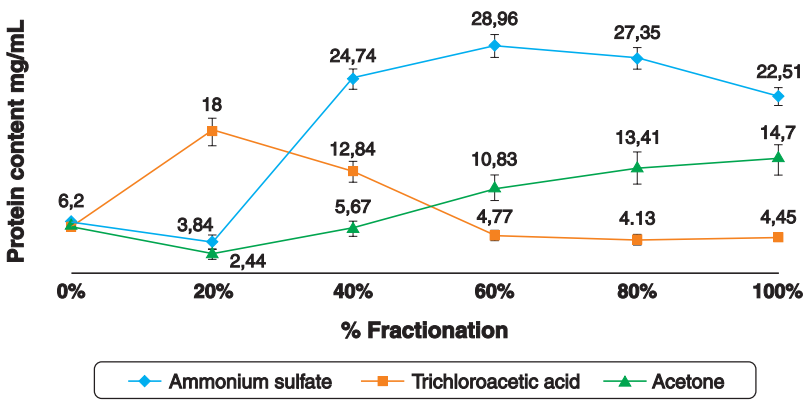

(C) Tyrophagus putrescentiae

Figure 4

Performance of the methods used for protein precipitation ( $\mathrm{mg} \mathrm{mL}^{-1}$ ) in dust mite extracts

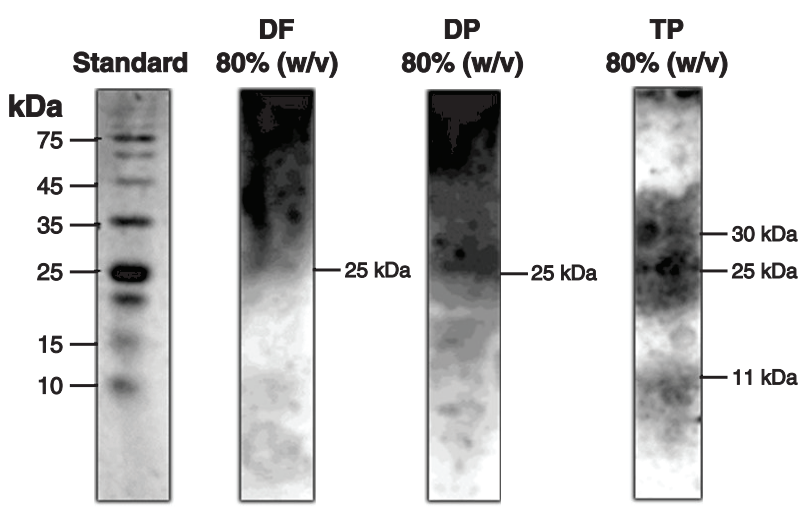

Figure 5

Immunoblotting for extracts of mites Dermatophagoides farinae (DF), Dermatophagoides pteronyssinus (DP) and Tyrophagus putrescentiae (TP) with ammonium sulfate at a saturation percentage of $80 \%(\mathrm{w} / \mathrm{v})$

\section{Conclusion}

Studies in the area of allergies and immunotherapies have great interest in purified fractions of dust mite allergens due to the low concentrations of these biomolecules in the final extraction process. Thus, the application of pre-purification and concentration techniques are well accepted for this purpose. The data presented in this paper show that the $\left(\mathrm{NH}_{4}\right)_{2} \mathrm{SO}_{4}$ fractionation process is a feasible way to obtain a more concentrated extract and that it can be used in immunodetection methods without previous salt removal, such as western blotting. The method to be applied, however, should be chosen considering the purpose of concentration and/or pre-purification.

\section{Acknowledgment}

We thank the Laboratory of Allergen Extracts LTDA, Brazil, for laboratory support.

\section{References}

1. Sun C, Liu W, Wang X, Li B, Cai J, Zou Z, et al. Associations of household dust mites (Der p 1 and Der $f$ 1) with childhood health outcomes masked by avoidance behaviors. Build Environ. 2019;151(January):198-206.

2. Rigonato-oliveira NC, Brito AA De, Vitoretti LB, Moraes GDC, Gonçalves T, Herculano KZ, et al. Effect of Low-Level Laser Therapy ( LLLT) in Pulmonary Inflammation in Asthma Induced by House Dust Mite ( HDM ): Dosimetry Study. Int Jounal Inflamm. 2019;2019:12. 
3. Mihos F das CSS, Pereira PR, Matos AB de A, Mergh CV, Cruz $\mathrm{MQ}$ da. Study of protein profile and immunochemical reactivity for extracts of $\mathrm{D}$. farinae, D. pteronyssinus and $\mathrm{B}$. tropicalis mites in the city of Rio de Janeiro, Brazil. Arq Asma, Alerg e Imunol. 2017;1(4):379-86.

4. Herman J, Thelen N, Smargiasso N, Mailleux AC, Luxen A, Cloes $M$, et al. Der $p 1$ is the primary activator of der $p 3$, der $p 6$ and der $p 9$ the proteolytic allergens produced by the house dust mite Dermatophagoides pteronyssinus. Biochim Biophys Acta - Gen Subj. 2014;1840(3):1117-24.

5. Thomas WR, Smith W-A, Hales BJ. The allergenic specificities of the house dust mite. Chang Gung Med J. 2004;27(8):563-9.

6. Boonpiyathad T, van de Veen W, Wirz O, Sokolowska M, Rückert B, Tan G, et al. Role of Der p 1-specific B cells in immune tolerance during 2 years of house dust mite-specific immunotherapy. J Allergy Clin Immunol. 2019 Mar;143(3):1077-1086.e10.

7. Malet A, Azpeitia A, Gutiérrez D, Moreno F, San Miguel Moncín M del M, Cumplido JA, et al. Comprehensive study of patients' compliance with sublingual immunotherapy in house dust mite perennial allergic rhinitis. Adv Ther. 2016 Jul;33(7):1199-214.

8. Colloff MJ. Dust mites. Netherlands: Springer; 2009. p. 1-583.

9. Turkheimer E, Waldron M. The Role and Efficiency of Ammonium Sulphate Precipitation in Purification Process of Papain Crude Extract. Psychol Bull. 2019;126(1):21.

10. Rajalingam D, Loftis C, Xu JJ, Kumar TKS. Trichloroacetic acidinduced protein precipitation involves the reversible association of a stable partially structured intermediate. Protein Sci. 2009;18(5):980-93.

11. Fic E, Kedracka-Krok S, Jankowska U, Pirog A, DziedzickaWasylewska M. Comparison of protein precipitation methods for various rat brain structures prior to proteomic analysis. Electrophoresis. 2010;31(21):3573-9.
12. Greenberg NA, Shipe WF. Comparison of the abilities of trichloroacetic, picric, sulfosalicylic, and tungstic acids to precipitate protein hydrolysates and proteins. Journal. J Food Sci. 1979;44(6):735-7.

13. Yvon MCC, Pélissier JP. Solubility of peptides in trichloroacetic acid (TCA) solu tions. Int $\mathrm{J}$ Pept Protein Res Haguenau. 1989;34(1):166-76.

14. Mihos F, Paiva V, Pereira P, Matos A, Cruz M. Immunological analysis of allergenic cross-reactivity between Cheyletus malaccensis and Dermatophagoides farinae, Dermatophagoides pteronyssinus and Blomia tropicalis. Arq Asma Alerg Imunol. 2018;2(2):247-52.

15. Flechtmann CHW. Elements of Acarology. 1st ed. São Paulo: Nobel; 1975. p. 9-339.

16. Fedatto LM. Caracterização de proteases extracelulares produzidas por Xylella fastidiosa de citros e videira [thesis]. Piracicaba (SP): ESALQ/CENA-USP; 2004.

17. Lowry OH, Rosebrough J, Lewis A, RandalR. Medición de proteínas con el reactivo de fenol Folin. J Biol Chem. 1951;193(1):265-75.

18. Laemmli UK. Cleavage of Structural Proteins during the Asssembly of the Head of Bacteriophage T4. Nature. 1970 Aug $15 ; 227(5259): 680-5$.

No conflicts of interest were declared associated with the publication of this article.

Corresponding author:

Francisca das Chagas Sobral Silva

E-mail: franciskasobral@gmail.com 